\title{
Interventional treatment of haemodynamically interrupted aortic arch with stent implantation in a 9-year-old patient - a case report
}

Leczenie interwencyjne hemodynamicznie przerwanego łuku aorty z wykorzystaniem stentu u 9-letniego pacjenta - opis przypadku

\author{
Paweł Dryżek ${ }^{1}$, Sebastian Góreczny', Beata Politowska ${ }^{1}$, Tomasz Moszura ${ }^{1}$, Artur Kobielski ${ }^{2}$, Andrzej Sysa ${ }^{1}$ \\ 1Department of Cardiology, Polish Mother's Memorial Hospital Research Institute, Lodz, Poland \\ 2Department of Paediatric Radiology, Clinical University Hospital no. 4, Lodz, Poland
}

Post Kardiol Interw 2011; 7, 2 (24): 188-192

DOI: $10.5114 /$ pwki.2011.23174

\begin{abstract}
A case of percutaneous treatment of haemodynamically interrupted aortic arch in a 9-year-old patient is reported. Congenital heart disease was diagnosed late in school age during routine physical examination, which revealed arterial hypertension. In further non-invasive diagnostic tests, echocardiography and computed tomography, critical coarctation of aorta was visualized. The patient underwent left heart catheterization with CP stent implantation. The stent fully expanded the stenosed aortic isthmus to $14 \mathrm{~mm}$ with no pressure gradient in direct haemodynamic measurement. No complications during or after the intervention were observed. In oneyear follow-up the patient remains asymptomatic with no signs of restenosis.
\end{abstract}

Key words: coarctation of aorta, stent, interventional treatment

\section{Streszczenie}

W artykule przedstawiono przypadek leczenia interwencyjnego hemodynamicznie przerwanego łuku aorty u 9-letniego pacjenta. Wrodzoną wadę serca rozpoznano dopiero w wieku szkolnym, stwierdzając w trakcie okresowego badania pediatrycznego nadciśnienie tętnicze. W wykonanych badaniach diagnostycznych, m.in. badaniu echokardiograficznym i wielorzędowej tomografii komputerowej, uwidoczniono krytyczne zwężenie cieśni aorty. Podczas interwencyjnego cewnikowania serca do cieśni aorty implantowano stent Cheatham-Platinum, uzyskując całkowite poszerzenie zwężonego miejsca do średnicy $14 \mathrm{~mm}$, bez gradientu ciśnień. W trakcie zabiegu oraz podczas rocznej obserwacji nie wystąpiły powikłania oraz nie stwierdzono nawrotu zwężenia.

Słowa kluczowe: koarktacja aorty, stent, leczenie interwencyjne

\section{Introduction}

Stenosis of the aortic isthmus is a congenital cardiovascular abnormality which can be treated surgically or with percutaneous intervention. Interventional treatment consists of balloon angioplasty and/or dilation of the aorta with stent implantation [1]. The use of balloon catheters for dilation of the aorta poses a risk of complications such as stenosis recurrence, aneurysm formation or even wall rupture. For that reason adolescents and older patients with stenosis of the aortic isthmus are treated with stent implantation. The aim of the study was to present an interventional treatment using a CP stent in an adolescent patient with critical stenosis of the aortic isthmus.

\section{Case report}

The 9-year-old boy was referred to the Department of Cardiology of the Institute by his primary physician because of arterial hypertension (max. 160/90 mmHg) and suspicion of aortic isthmus stenosis. On admission the patient was in good general condition, without symptoms of heart 
failure, with markedly better developed upper part of the body and with hypertension measured on the upper extremities $(140 / 70 \mathrm{mmHg})$, but with no pulse on the lower extremities. Electrocardiogram showed signs of left ventricular hypertrophy. Echocardiographic examination confirmed the presence of aortic isthmus stenosis with a gradient of $62 \mathrm{mmHg}$ on Doppler imaging with an abnormal flow pattern in the abdominal aorta $(V \max -0.7 \mathrm{~m} / \mathrm{s})$. Additionally a markedly hypertrophied left ventricle with normal muscle contractility (EF 65\%) and a bicuspid aortic valve without signs of valve dysfunction were visualized. Before the qualification for treatment the patient underwent angio-computed tomography (angio-CT) of the chest. The study showed aortic isthmus stenosis located 12-13 $\mathrm{mm}$ below the origin of the left subclavian artery with $4 \mathrm{~mm}$ diameter of the lumen and aortic dimensions of $11 \mathrm{~mm}$ above the stenosis and $14 \mathrm{~mm}$ below the stenosis. Collateral circulation through intercostal arteries, internal thoracic arteries and paravertebral plexi was demonstrated (figs. 1, 2).

\section{Procedure description}

Under general anaesthesia, a $5 \mathrm{~F}$ intravascular sheath was placed in the right femoral artery and used to introduce a 4 F Pigtail (Cook) catheter over 0.032 " wire into the descending aorta below the site of stenosis. Pressure
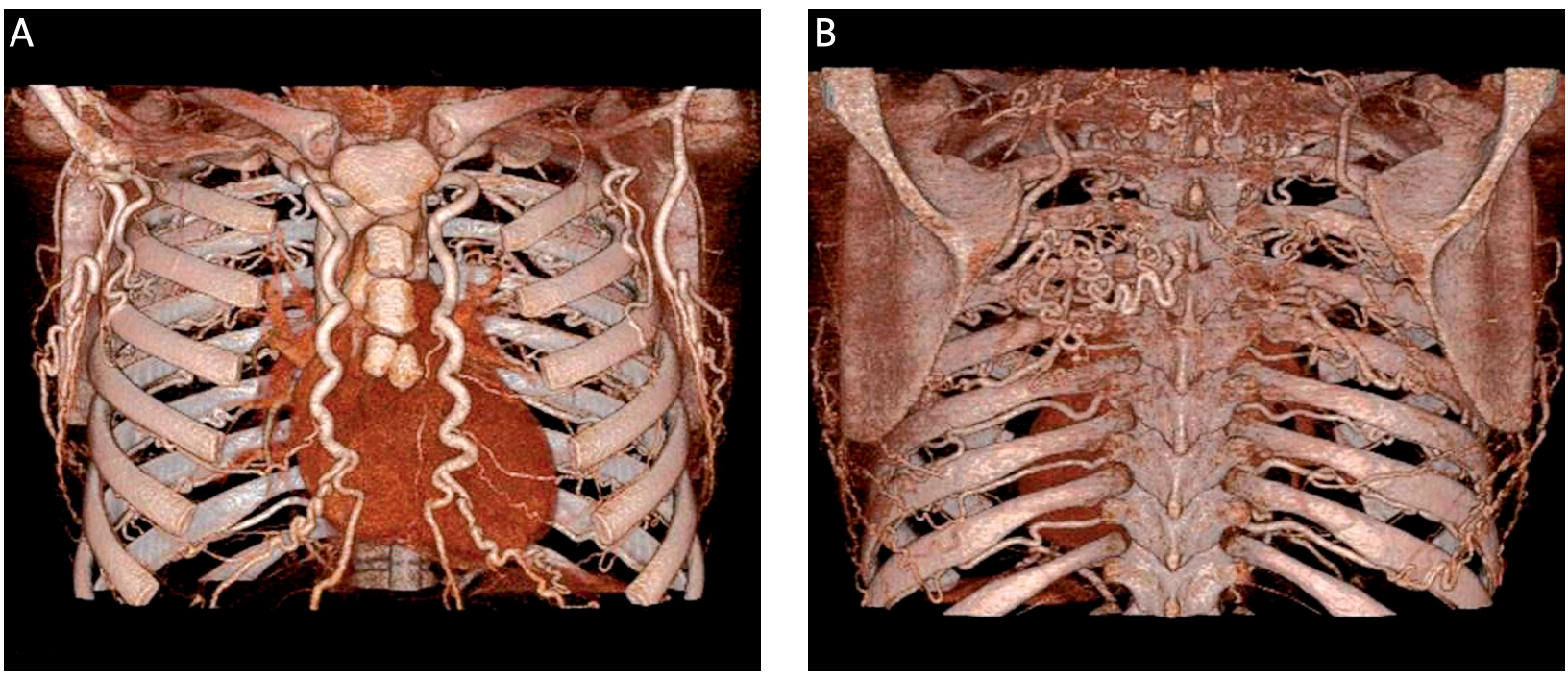

Fig. 1 A, B. Angio-CT 3D reconstruction. Well-developed collateral circulation through internal mammary and intercostal arteries

Ryc. 1 A, B. Trójwymiarowa rekonstrukcja angio-TK. Widoczne dobrze rozwinięte naczynia krążenia obocznego: tętnice piersiowe wewnętrzne, międzyżebrowe
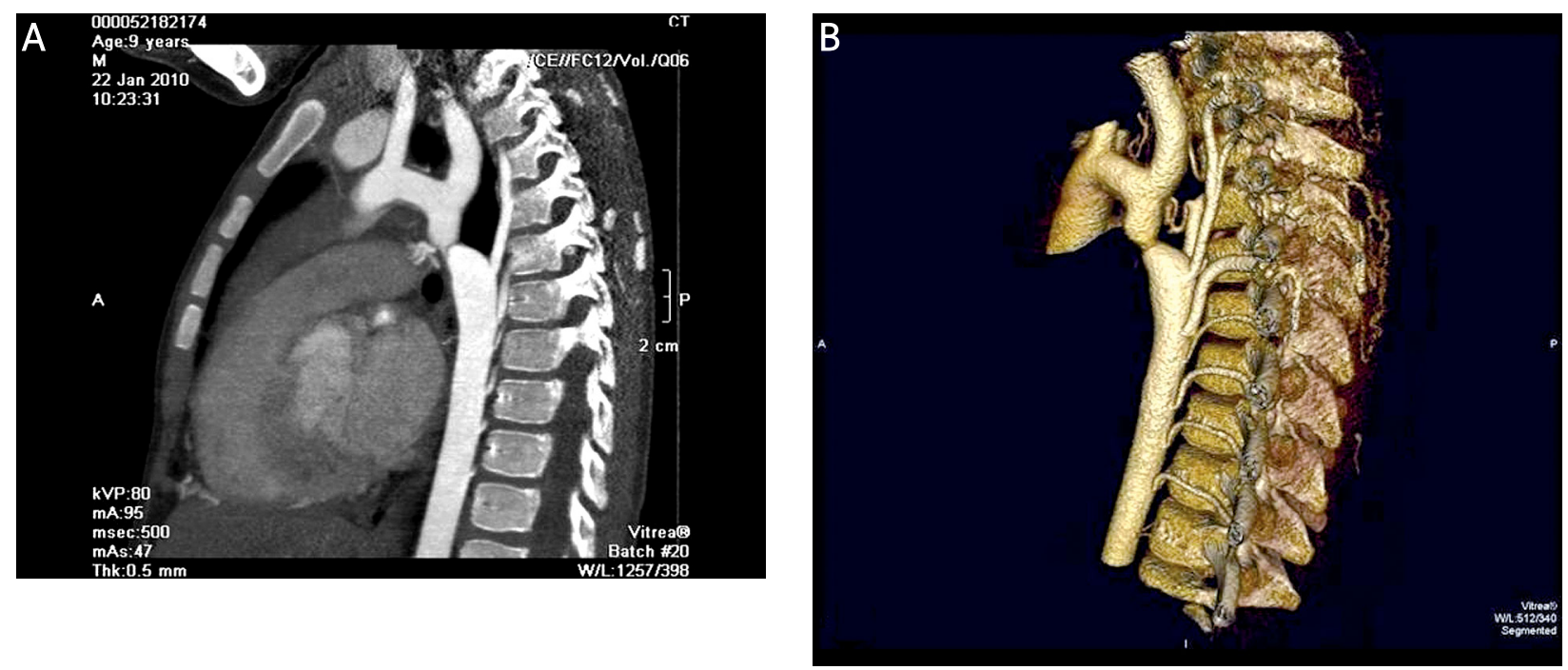

Fig. 2. A - multislice computed tomography. B - 3D reconstruction

Ryc. 2. A - wielorzędowa tomografia komputerowa. B - rekonstrukcja trójwymiarowa 

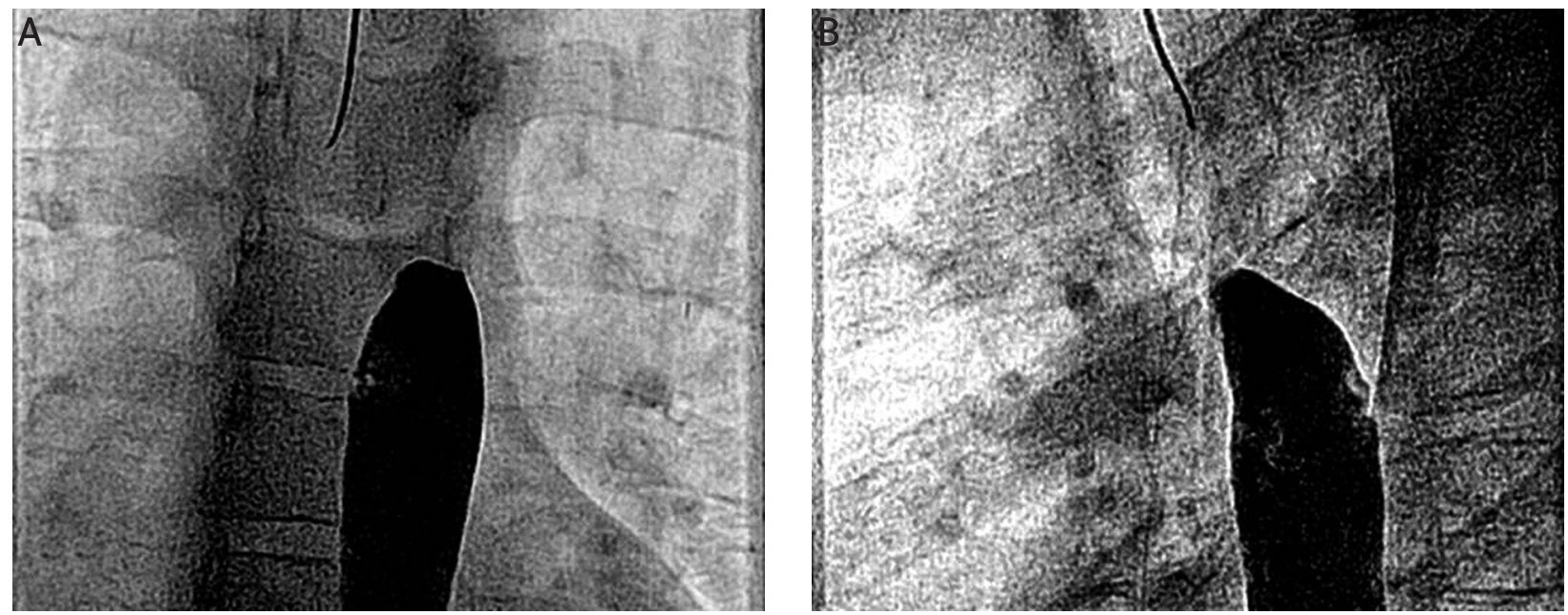

Fig. 3. Angiography of the descending aorta below critical stenosis. A - antero-posterior projection. B - lateral projection

Ryc. 3. Angiografia z aorty zstępującej poniżej krytycznego zwężenia. $A$ - projekcja przednio-tylna. B - projekcja boczna

measurement and angiography in antero-lateral, left lateral and left oblique 60 projections were performed. Descending aorta of a $14 \mathrm{~mm}$ diameter without contrast medium inflow into the aortic arch above the site of stenosis was demonstrated. Blood inflow to the descending aorta through many collateral vessels was detected. After many unsuccessful attempts a 0.014" coronary guide-wire (Terumo) was finally introduced through a $4 \mathrm{~F}$ multipurpose catheter (Cordis, JohnsonJohnson) to the aortic arch and ascending aorta with subsequent catheter-based pressure measurements. After exchange for a 4 F Pigtail catheter placed in the ascending

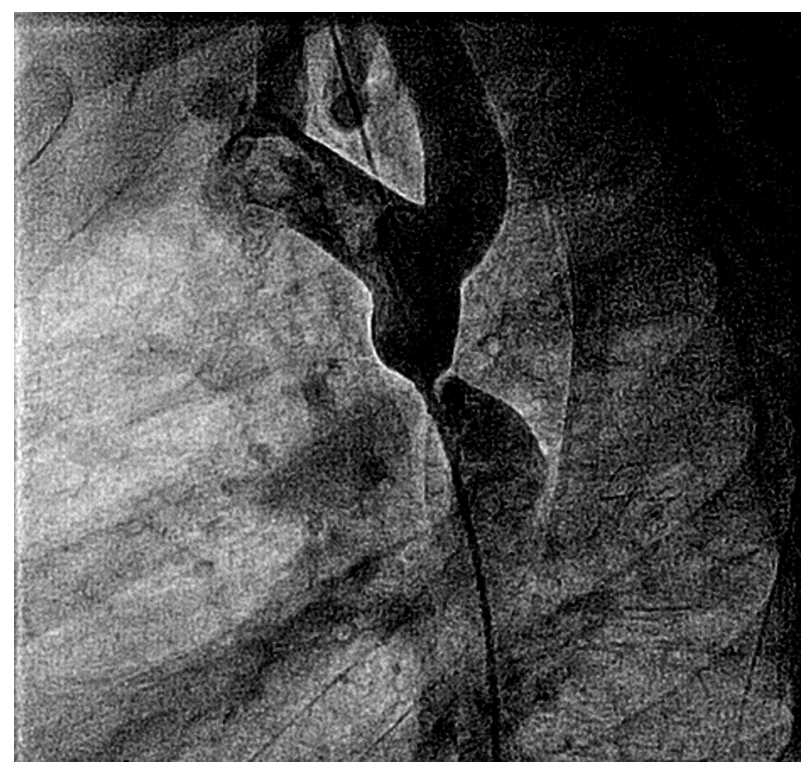

Fig. 4. Angiography of the aortic arch. Critical isthmus stenosis. Lateral projection

Ryc. 4. Angiografia z łuku aorty. Widoczne krytyczne zwężenie cieśni. Projekcja boczna aorta, angiography in several projections was performed. This allowed for visualization of a wide ascending aorta, left-sided aortic arch of $11 \mathrm{~mm}$ diameter with normal origin of brain-supplying arteries and a critically stenosed aorta of $2 \mathrm{~mm}$ diameter with significant post-stenotic dilation of the descending aorta below the stenosis of up to $14 \mathrm{~mm}$. Potent collateral vessels originating from the left and right subclavian arteries were disclosed. The pressure in the ascending aorta was $120 / 79 / 100 \mathrm{mmHg}$ and in the descending aorta $69 / 61 / 66 \mathrm{mmHg}$ with a pressure gradient of $51 \mathrm{mmHg}$. A balloon catheter Advance $6 \times 20 \mathrm{~mm}$ (Cordis, Johnson-Johnson) was introduced into the aortic isthmus and expanded under pressure of 6 atmospheres. Control angiography showed enlargement of the isthmus to $4 \mathrm{~mm}$. Subsequently a CP $8 Z 34$ stent (NuMed) was implanted on the BIP balloon 14/7/35 mm (NuMed) through a long $10 \mathrm{~F}$ Mullins intravascular sheath (Cook). During the procedure $3000 \mathrm{IU}$ of heparin was administered (figs. 3, 4).

\section{Results}

Control angiography showed a fully expanded stent of $14 \mathrm{~mm}$ diameter in the descending part of the aortic arch with a visible free contrast flow. There was no pressure gradient in the aorta on the haemodynamic measurements. A turbulent flow $(V \max -2.2 \mathrm{~m} / \mathrm{s})$ was recorded at the site of the implanted stent in echocardiographic examination with a normal flow in the abdominal aorta ( Vmax - 1.95 $\mathrm{m} / \mathrm{s}$ ). Because of the elevated systolic arterial pressure ( $\max$ $156 / 73 \mathrm{mmHg}$ ) after the procedure, treatment with a $\beta$ blocker (Metocard) was initiated, which led to normalization of the arterial pressure (max. 128/65 $\mathrm{mmHg}$ ).

The patient was discharged home after 7 days and instructed to continue his pharmacotherapy (Metocard), to periodically attend ambulatory visits and to use 

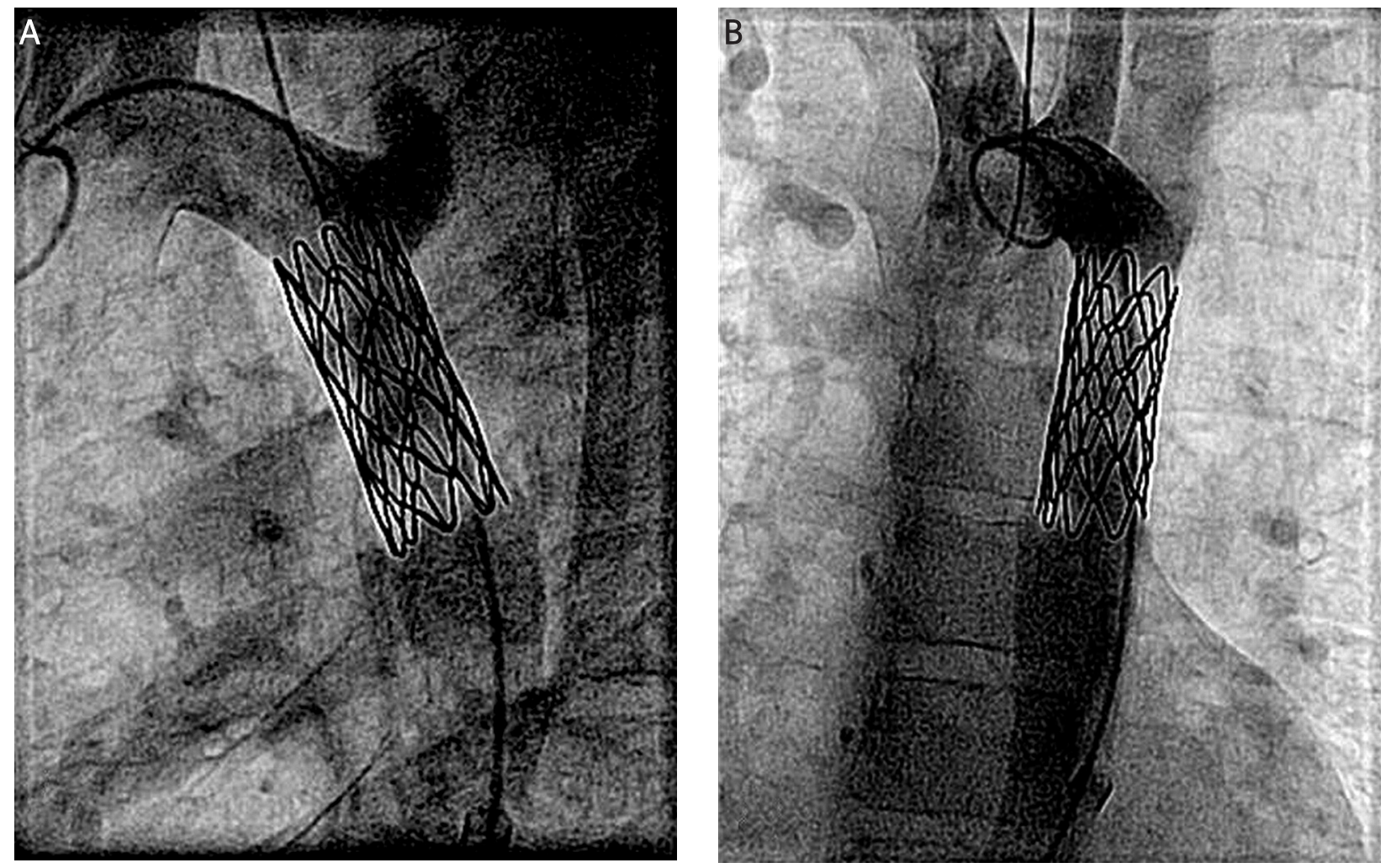

Fig. 5. Angiography of the ascending aorta after stent implantation. A - lateral projection. B - antero-posterior projection

Ryc. 5. Angiografia z aorty wstępującej po implantacji stentu. $A$ - projekcja boczna. B - projekcja przednio-tylna

antibiotic prophylaxis of the infective myocarditis for 6 months.

The patient remains in a good general condition at 12 months, without any treatment complications or stenosis recurrence. Pharmacotherapy of arterial hypertension is continued (fig. 5).

\section{Discussion}

Stenosis of the aortic isthmus is a congenital cardiovascular defect with a prevalence of $5-8 \%$. The primary mode of treatment in newborns and neonates is surgery, while in older patients treatment of primary stenosis of the aortic isthmus may include interventions such as balloon angioplasty and/or stent implantation [2-4]. Significant stenosis of the aortic isthmus is usually diagnosed in the first period of life. In older patients arterial hypertension is a frequent finding leading to suspicion and diagnosis of the disease. Stents have been used for the treatment of primary and recurrent aortic isthmus stenosis for several years. They lower the risk of complications, especially aneurysm formation in the stenosed vessel. Since their introduction the risk of aneurysm formation in the case of aortic isthmus stenosis does not exceed a few percent $[5,6]$. In patients with primary or secondary aortic isthmus stenosis who finished the growth period and in adults stent implantation is usually a definitive and final treatment. In contrast, treatment of tight aortic isthmus stenosis in children using stents requires repeated heart catheterization in order to expand the stent to the actual vessel diameter. A satisfactory result of treatment with balloon angioplasty, except in newborns and early neonates, is achieved in $60-75 \%$ of cases, with a percentage of aortic isthmus restenosis of a few to a dozen percent [8]. The same complication after stent implantation does not exceed a few percent. In the case of a critical aortic isthmus stenosis, balloon angioplasty does not allow one to fully dilate the stenosed site and to completely abolish the pressure gradient, while at the same time it is related to very high risk of complications. In these situations interventional treatment with stent implantation is a feasible and effective method [9]. In the case of primary aortic isthmus stenosis most authors suggest the use of stents without balloon angioplasty to limit the risk of aortic wall injury [10]. In our case pre-dilation of the critically stenosed aortic isthmus was necessary for safe and atraumatic to the aortic wall introduction of the long intravascular sheath used for stent implantation through the site of stenosis. In the case of a haemodynamically interrupted aortic arch and the lack of possibility for a retrograde crossing with a catheter from the descending aorta to the aortic arch an attempt to cross using a subclavian access or femoral vein access followed by interatrial septum puncture can be made [11]. CP stents 
may be implanted on balloons used for angioplasty or on the BIP type balloon (balloon in balloon). Stent implantation with a double balloon allows safe and correct positioning of the stent before its complete expansion [12]. A limitation of this method is the necessity to use a large diameter intravascular sheath. Therefore it should be used in patients with body mass higher than 25-30 kg [9]. Critical isthmus stenosis may be treated with a covered stent, which lowers the risk of aortic rupture, but it should be noted that this type of stent may lead to flow cessation in the vertebral arteries and to spinal cord injury. The size of the balloon used for stent implantation is based on the distal aortic arch diameter and/or descending aorta diameter assessed at the level of the diaphragm. According to Cheatham, balloon size should not be larger than $2 \mathrm{~mm}$ greater than the aortic arch diameter [12]. Stent implantation may cause complications such as stent fracture or stent dislocation, thrombotic incidents or aortic wall rupture [6]. The risk of complications is higher for larger size balloons [13].

Arterial hypertension related to aortic isthmus stenosis does not always rapidly drop and eventually normalizes after surgical or percutaneous treatment. Patients above 4-6 years of age usually require life-long pharmacological treatment due to persistent arterial hypertension, although in most cases (50-70\%) the pressure values remain within the normal range [8].

\section{Conclusions}

Interventional treatment of haemodynamically interrupted aortic arch or critically stenosed aortic isthmus is possible even in patients diagnosed in adolescence.

\section{References}

1. Szkutnik M, Białkowski J, Fiszer R. Percutaneous dilatation of aortic coarctation with balloon angioplasty and /or stent implantationown experience Post Kardiol Interw 2010; 6: 1-5.
2. Ewert P, Peters B, Nagdyman N, et al. Early and mid-term results with the Growth stent- a possible concept for transcatheter treatment of aortic coarctation from infancy to adulthood by stent implantation? Catheter Cardiovasc Interv 2008; 71: 120-126.

3. Qureshi SA, Zubrzycka M, Brzeźińska-Rajszys G, et al. Use of the covered Cheatham-Platinum stents in aortic coarctation and recoarctation. Cardiol Young 2004; 14: 50-54.

4. Chessa M, Carozza M, Butera G, et al. Results and mid-long-term follow-up of stent implantation for native and recurrent coarctation of the aorta. Eur Heart J 2005; 26: 2728-2732.

5. Forbes TJ, Garekar S, Amin Z, et al. Procedural results and acute complication in stenting native and recurrent coarctation of the aorta in patients over 4 years of age: a multi-institutional study. Cather Cardiovasc Interv 2007; 70: 569-577.

6. Tzifa A, Ewert P, Brzezińska-Rajszys G, et al. Covered CheathamPlatinum stents for aortic coarctation: early and intermediateterm results. J Am Coll Cardiol 2006; 47: 1457-1463.

7. Dryżek P, Moszura T, Politowska B, et al. Leczenie zwężenia cieśni aorty pierwotnego lub wtórnego u dzieci, młodzieży i młodych dorosłych z wykorzystaniem stentów typu Cheatham-Platinum. Pol Przegl Kardiol 2006; 8: 325-329.

8. Fawzy ME, Awad M, Hassan W, et al. Long-term outcome (up to 15 years) of balloon angioplasty of discrete native coarctation of the aorta in adolescents and adults. J Am Coll Cardiol 2004; 43: 1062-1067.

9. Ewert P, Schubert S, Peters B, et al. The CP stent-short, long, covered-for treatment of aortic coarctation stenosis of pulmonary arteries and caval veins and Fontan anastamosis in children an adults: an evaluation of 60 stent in 53 patients. Heart 2005; 91: 948-953.

10. Thanopoulos BD, Hadjinikolaou L, Konstadopoulou GN, et al. Stent treatment for coarctation of the aorta:intermediate term follow up and technical considerations. Heart 2000; 84: 65-70.

11. Kusa J, Szkutnik M, Białkowski J. Percutaneous reconstruction of the continuity of a functionally interrupted aortic arch using a stent. Cardiol J 2008; 15: 80-84.

12. Cheatham JP. Stenting of coarctation of the aorta. Catheter Cardiovasc Interv 2001; 54: 112-125.

13. Forbes TJ, Matisoff D, Dysart J, et al. Treatment of coexistent coarctation and aneurysm of the aorta with covered stent in a pediatric patient. Pediatr Cardiol 2003; 24: 289-291. 